\title{
Protective Effects of Nephrolepis exaltata Mask against Blood Glucose Level (A Study of Wistar Rats with Chronic Exposure to Nanosilica)
}

\author{
Evan Savero Widiono ${ }^{1 *}$, Ariosta Setyadi ${ }^{2}$, Awal Prasetyo ${ }^{3}$, Udadi Sadhana ${ }^{4}$ and Agus Subagio ${ }^{5}$ \\ 'Diponegoro University, Semarang City,Central Java, Indonesia; evanwidiono@yahoo.co.id \\ 2Department of Clinical Pathology, Diponegoro University, Semarang City, Central Java, Indonesia; \\ setyadi85@yahoo.co.id \\ 32Department of ENT, Diponegoro University, Semarang City, Central Java, Indonesia; awalpras@yahoo.com \\ ${ }^{4}$ Department of Anatomical Pathology Diponegoro University, Semarang City, Central Java, Indonesia; \\ udadisadhana@yahoo.com \\ ${ }^{5}$ Department of Physics, Diponegoro University, Semarang City, Central Java, Indonesia; \\ agus_fadhil@yahoo.com
}

\begin{abstract}
Introduction: Silica is a substance utilized as fertilizer. Nano-sized silica particles can turn into free radical, thus inducing oxidative stress which in the long term can induce diabetes mellitus. Mask made from Boston sword fern plant (Nephrolepis exaltata) can prevent blood glucose level elevation due to chronic inhalation of nanosilica. Objectives: To determine the effect of wearing Nephrolepis exaltata mask against blood glucose level of Wistar rats with chronic exposure to nanosilica. Methods: It includes True experimental study with Pretest-Posttest Only Control Group design. The sample was a group of 28 male Wistar rats meeting inclusion and exclusion criterias. Samples were randomly divided into 4 groups, group 1 was exposed to $175 \mathrm{mg} / \mathrm{L}$ nanosilica fertilizer, group 2 was exposed to $175 \mathrm{mg} / \mathrm{L}$ nanosilica fertilizer and was given regular mask, group 3 was exposed to $175 \mathrm{mg} / \mathrm{L}$ nanosilica fertilizer and was given $N$. exaltata herbal mask, group 4 was given Streptozotocin injection in the dose of $40 \mathrm{mg} / \mathrm{kg}$. Exposure was given three times a day for 28 days. Blood glucose level testing was done before and after exposure. Rats were terminated on 29th day. Obtained data as in rats' blood glucose levels was then analyzed with Annova and Post Hoc test. Results: After statistical analysis, the difference between blood glucose levels before and after exposure differs significantly between group 3 and $4(p=0,021)$, insignificantly between group 1 and $2(p=1,00)$, group 1 and $3(p=0,27)$, group 1 and $4(p=1,00)$, group 2 and $3(p=1,00)$, group 2 and $4(p=0,21)$. Conclusions: Nanosilica inhalation and streptozotocin induction were proved to elevate blood glucose level in Wistar rats; wearing Nephrolepis exaltata herbal mask was proved to prevent blood glucose elevation in Wistar rats with chronic inhalation of nanosilica.
\end{abstract}

Keywords: Blood Glucose Level, Nanosilica Fertilizer, Nephrolepis exaltata

\section{Introduction}

Diabetes Mellitus (DM) is a cluster of metabolic disorder with high blood glucose level. According to World Health Organization (WHO) diabetes mellitus is the 6th most common death cause ${ }^{1}$. Health is often discussed in urban areas because urban residents have higher risk factors of developing diseases despite having sufficient health care.

Particulate Matter (PM) is a term describing solid or liquid particle found in air both in large or small size. Urban area is one of the areas with high PM concentration, which affects respiratory tracts 2 . Research showed

${ }^{*}$ Author for correspondence 
that as PM concentration in air increases the prevalence of DM increases proportionally ${ }^{3}$.

Oxidative stress is an imbalance between free radicals and antioxidants in the body ${ }^{4}$. Oxidative stress can happen from PM getting inside the body. A research has shown that systemic oxidative stress associates with insulin resistance ${ }^{5}$.

Silica is a PM component which is sized $0,02 \mu \mathrm{m}$ thus can be inhaled into respiratory tracts. It can induce inflammation and scar tissue formation in respiratory tracts ${ }^{2.4}$. Utilization of nano sized particles is gaining fame in various fields, among them is nanosilica as basic ingredient of fertilizer ${ }^{6}$.

Indonesian farmers with constant exposure to nanosilica fertilizer can develop serious health problems including elevated blood glucose level ${ }^{7}$. In light of this situation, we aim to figure out the effect of nanosilica particle against blood glucose level elevation compared to streptozotocin induced blood glucose level elevation.

Wearing mask is an attempt to reduce risks of developing diseases and to prevent the exposure of pollutant. Nephrolepis exaltata ( $N$. exaltata) mask is highly effective in reducing risks of developing disease ${ }^{8}$. In an earlier research $N$. exaltata was found to be able to absorb formaldehyde, xylene, tricholoethylene, and carbon monoxide from air which are the causative agents of oxidative stress. Given this situation, we aim to study the effect of wearing N. exaltata mask against oxidative stress due to chronic nanosilica exposure by evaluating the blood glucose levels in rats?

\section{Materials and Methods}

\subsection{Samples and Tested Variables}

This study is a true experimental study with pretest-post test only design, with 28 male Wistar rats as the studied samples. Tested variables were given for 28 days. The samples were divided into 4 experimental groups (Table 1), each group had 7 samples meeting these criterias:

1. Inclusion criterias: 1. Male Wistar rat, 2. Age 7-9 week, 3. Weights 250-300 gram, 4. Has no anatomical anomaly, and 5. Blood glucose level under $200 \mathrm{mg} / \mathrm{dL}$

2. Exclusion criterias: Rat dies during adaptation and variable testing.
Prior to variable testing all Wistar rats were acclimatized to the cage and standard feeding ad libitum for 1 week. The rats were then given the tested variables in accordance to grouping for 28 days. Blood glucose level were measured before and after variable testing by taking $1 \mathrm{~mL}$ of blood sample from tail vein with anesthesia ${ }^{10}$. Obtained blood sample were tested with blood glucose strip connected to a glucose meter.

Table 1. Experimental groups

\begin{tabular}{|l|l|}
\hline Group & Tested Variable \\
\hline P1 & $\begin{array}{l}\text { Wistar rats were sprayed with } 175 \mathrm{mg} / \mathrm{L} \text { of } \\
\text { nanosilica fertilizer for } 28 \text { days }\end{array}$ \\
\hline P2 & $\begin{array}{l}\text { Wistar rats were sprayed with } 175 \mathrm{mg} / \mathrm{L} \text { of } \\
\text { nanosilica fertilizer for } 28 \text { days and were given } \\
\text { regular mask filter }\end{array}$ \\
\hline P3 & $\begin{array}{l}\text { Wistar rats were sprayed with } 175 \mathrm{mg} / \mathrm{L} \text { of } \\
\text { nanosilica fertilizer for } 28 \text { days and were given } \\
\text { N. exaltata at a herbal filter }\end{array}$ \\
\hline P4 & $\begin{array}{l}\text { Wistar rats were injected with } 40 \mathrm{mg} / \mathrm{kg} \text { dose of } \\
\text { Streptozotocin }\end{array}$ \\
\hline
\end{tabular}

\subsection{Data Analysis}

The data of Wistar rats' blood glucose levels were put under Shapiro-Wilk normality test. If the data were normally distributed the analysis would proceed with Oneway Anova, else ways data will be transformed to normalize the distribution. If data remained abnormally distributed analysis proceeded with Mann-Whitney test. $\mathrm{P}$-value under 0,05 determined significance of difference between the groups.

\section{Results}

\subsection{Pretest Blood Glucose Level}

Data in group P1 were abnormally distributed (Figure 1). Normally distributed data in group P2 $(0,18)$, P3 $(0,68)$, P4 $(0,49) ;(p>0,05)$. Significance of difference between pretest blood glucose levels in the four experimental groups were tested with Anova/ Kruskal-Wallis test.

Significant difference was found from Kruskal-Wallis test (Table 2), analysis proceeded with Mann-Whitney test (Table 3). The test found significant difference between 
Table 2. Difference between prêt test, posttest, and deviation blood glucose levels in 4 experimental groups

\begin{tabular}{|c|c|c|c|c|c|c|}
\hline \multirow[t]{2}{*}{ Group } & \multicolumn{2}{|l|}{ Prettest $\dagger$} & \multicolumn{2}{|l|}{ Posttest } & \multicolumn{2}{|l|}{ Deviation§ } \\
\hline & $\begin{array}{l}\text { Mean } \pm \\
\text { standard } \\
\text { deviation }\end{array}$ & $\begin{array}{l}\text { Median (Min- } \\
\text { Max) }\end{array}$ & $\begin{array}{l}\text { Mean } \pm \\
\text { standard } \\
\text { deviation }\end{array}$ & $\begin{array}{l}\text { Median } \\
\text { (Min-Max) }\end{array}$ & $\begin{array}{l}\text { Mean } \pm \\
\text { standard } \\
\text { deviation }\end{array}$ & $\begin{array}{l}\text { Median } \\
\text { (Min-Max) }\end{array}$ \\
\hline $\begin{array}{l}\text { Group } \\
1\end{array}$ & $\begin{array}{l}85,40 \pm 2,60 \\
\mathrm{mg} / \mathrm{dL}\end{array}$ & $\begin{array}{l}88(75-88) \mathrm{mg} / \\
\mathrm{dL}\end{array}$ & $\begin{array}{l}99,80 \pm 3,90 \\
\mathrm{mg} / \mathrm{dL}\end{array}$ & $\begin{array}{l}100(88-113) \\
\mathrm{mg} / \mathrm{dL}\end{array}$ & $\begin{array}{l}14,40 \pm 4,50 \\
\mathrm{mg} / \mathrm{dL}\end{array}$ & $\begin{array}{l}12(0-25) \\
\mathrm{mg} / \mathrm{dL}\end{array}$ \\
\hline $\begin{array}{l}\text { Group } \\
2\end{array}$ & $\begin{array}{l}80,40 \pm 5,40 \\
\mathrm{mg} / \mathrm{dL}\end{array}$ & $\begin{array}{l}75(71-99) \mathrm{mg} / \\
\mathrm{dL}\end{array}$ & $\begin{array}{l}83,40 \pm 13,92 \\
\mathrm{mg} / \mathrm{dL}\end{array}$ & $\begin{array}{l}100(32-107) \\
\mathrm{mg} / \mathrm{dL}\end{array}$ & $\begin{array}{l}3,00 \pm 12,71 \\
\mathrm{mg} / \mathrm{dL}\end{array}$ & $\begin{array}{l}5(-43-31) \\
\mathrm{mg} / \mathrm{dL}\end{array}$ \\
\hline $\begin{array}{l}\text { Group } \\
3\end{array}$ & $\begin{array}{l}91,20 \pm 7,03 \\
\mathrm{mg} / \mathrm{dL}\end{array}$ & $\begin{array}{l}90(75-113) \\
\mathrm{mg} / \mathrm{dL}\end{array}$ & $\begin{array}{l}81,80 \pm 3,74 \\
\mathrm{mg} / \mathrm{dL}\end{array}$ & $\begin{array}{l}84(69-92) \\
\mathrm{mg} / \mathrm{dL}\end{array}$ & $\begin{array}{l}-9,40 \pm 6,02 \\
\mathrm{mg} / \mathrm{dL}\end{array}$ & $\begin{array}{l}-9(29-9) \\
\mathrm{mg} / \mathrm{dL}\end{array}$ \\
\hline $\begin{array}{l}\text { Group } \\
4\end{array}$ & $\begin{array}{l}67,80 \pm 2,78 \\
\mathrm{mg} / \mathrm{dL}\end{array}$ & $\begin{array}{l}66(62-77) \mathrm{mg} / \\
\mathrm{dL}\end{array}$ & $\begin{array}{l}96,20 \pm 2,95 \\
\mathrm{mg} / \mathrm{dL}\end{array}$ & $\begin{array}{l}100(89-102) \\
\mathrm{mg} / \mathrm{dL}\end{array}$ & $\begin{array}{l}28,40 \pm 5,02 \\
\mathrm{mg} / \mathrm{dL}\end{array}$ & $\begin{array}{l}30(12-39) \\
\mathrm{mg} / \mathrm{dL}\end{array}$ \\
\hline
\end{tabular}

Test of significance used in pretest and posttest was Kruskal-Wall is

Test of significance used in deviation was Anova

$\dagger \mathrm{p}=0,020^{*}$

$\neq \mathrm{p}=0,143$

$\$ \mathrm{p}=0,021^{\star}$

*difference was significant if $\mathrm{p}<0,05$

group P1 and P4, group P3 and P4 ( $<<0,05)$. Difference was insignificant between group $\mathrm{P} 1$ and $\mathrm{P} 2$, as well as between group $\mathrm{P} 1$ and $\mathrm{P} 3$, group $\mathrm{P} 2$ and $\mathrm{P} 3$, group $\mathrm{P} 2$ and $\mathrm{P} 4$.

Table 3. Mann-Whitney significance test for difference of blood glucose levels

\begin{tabular}{|l|l|l|l|l|}
\hline & Group 1 & Group 2 & Group 3 & Group 4 \\
\hline Group 1 & & 0,193 & 0,387 & 0,013 \\
\hline Group 2 & 0,193 & & 0,141 & 0,072 \\
\hline Group 3 & 0,387 & 0,141 & & 0,016 \\
\hline Group 4 & 0,013 & 0,072 & 0,016 & \\
\hline
\end{tabular}

Test of significance was significant if $\mathrm{p}<0,05$

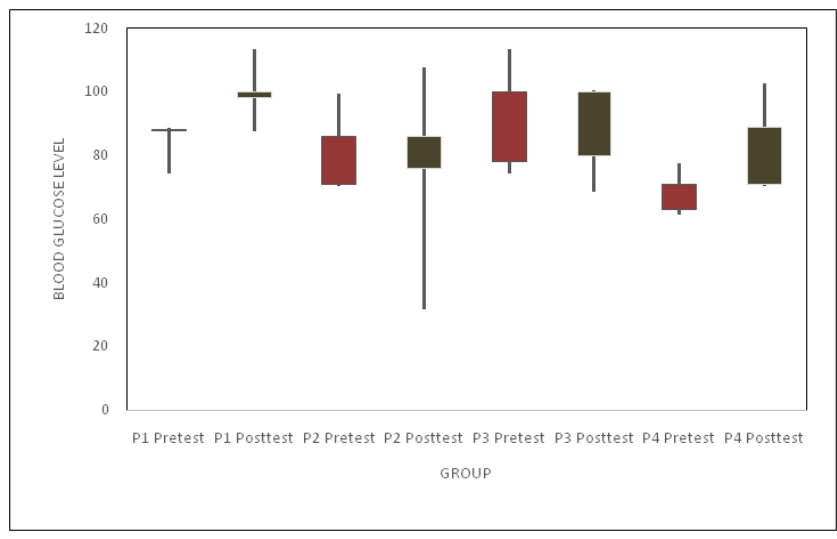

Figure 1. Boxplot graphic of pretest and posttest blood glucose level in each group.

\subsection{Posttest Blood Glucose Levels}

Data normally distributed $(\mathrm{p}>0,05)$ were found in group $\mathrm{P} 1(0,54) ; \mathrm{P} 2(0,10) ; \mathrm{P} 3(0,67)$ (Figure 1). Abnormally distributed data in group P4 was 0,03 . Significance of difference between posttest blood glucose levels in the four experimental groups were tested with Kruskal-Wallis test (Table 2).

Table 4. Post Hoc test on of blood glucose level deviation

\begin{tabular}{|l|l|l|l|l|}
\hline & Group 1 & Group 2 & Group 3 & Group 4 \\
\hline Group 1 & - & 1,00 & 0,27 & 1,00 \\
\hline Group 2 & 1,00 & - & 1,00 & 0,21 \\
\hline Group 3 & 0,27 & 1,00 & - & 0,201 \\
\hline Group 4 & 1,00 & 0,21 & 0,021 & - \\
\hline
\end{tabular}

Post Hoc test to analyze the significance of difference, deviation was significant if $\mathrm{p}<0,05$

\subsection{Blood Glucose Level Deviation}

Normally distributed data $(\mathrm{p}>0,05)$ were found in group P1 (0,50); P2(0,42); P3 (0,48); P4(0,53) (Figure 2). Whether the deviation of blood glucose level from pretest to posttest in the four experimental groups was signifi- 
cantly different was tested with Anova/ Kruskal-Wallis test.

Significant difference was found after Anova test (Table 2), analysis proceeded with Post Hoc test (Table 4). The test found significant difference in group P3 and P4 $(\mathrm{p}<0,05)$. Difference was insignificant between group P1 and $\mathrm{P} 2$, as well as between group $\mathrm{P} 1$ and $\mathrm{P} 3$, group $\mathrm{P} 1$ and P4, group P2 and P3, group P2 and P4.

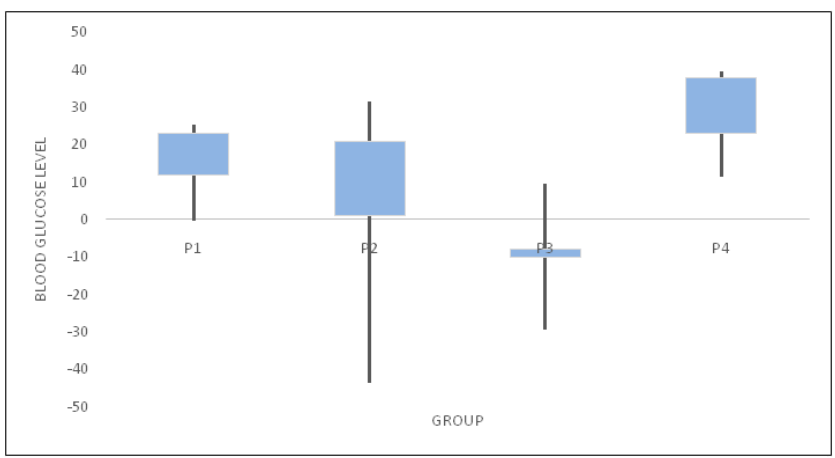

Figure 2. Boxplot graphic of blood glucose level in each group.

\section{Discussion}

Sample of this study was a group of 28 male Wistar rats meeting inclusion criterias. Samples were randomly divided into 4 groups. Rats were made acclimatized to the cage and standard feeding during the experiment.

Samples were divided into 4 groups for testing different variables: a control group induced with streptozotocin, experimental group exposed to $175 \mathrm{ml} / \mathrm{L}$ of nanosilica fertilizer inhalation, experimental group exposed to nanosilica fertilizer inhalation and given regular mask, experimental group exposed to nanosilica fertilizer inhalation and given $N$. exaltata mask. The variables were tested for 28 days. Rats' blood glucose levels were tested before and after variable testing using glucose meter.

Nanosilica, a $100 \mathrm{~nm}$ sized nano-particle can induce ROS formation inside the body ${ }^{11}$. High ROS concentration in body causes oxidative stress. Oxidative stress caused by ROS elevation is cytotoxic to cells of human body ${ }^{12}$. One of the affected components of the body is insulin receptor transduction signal in peripheral tissue which can cause insulin resistance in type II diabetes mellitus ${ }^{\underline{13}}$.

In this study the average blood glucose level deviation was elevated after nanosilica inhalation, which indicated that nanosilica inhalation causes blood glucose elevation in rats. The elevation of blood glucose caused by nano- silica inhalation was not significantly different from the elevation of blood glucose caused by streptozotocin induction. This suggests that elevated blood glucose caused by nanosilica inhalation can cause similar effect as the case with streptozotocin.

Regular mask used in this study is fabric mask that filters only large sized particles, it can't filter micro or nano sized particles ${ }^{14}$. This allows nano-particles to go through the mask.

In this study the average blood glucose level in Wistar rats exposed to nanosilica inhalation wearing regular mask was different from the Wistar rats exposed to nanosilica inhalation wearing N. exaltata herbal mask. Blood glucose level elevation after nanosilica inhalation in rats wearing herbal mask lowered while it elevated in rats wearing regular mask. Herbal mask nanosilica had shown to lower blood glucose elevation caused by nanosilica particles, although statistically the difference between the two groups was insignificant.

Researches show that $N$. exaltata herbal mask contains xanthone and mangifer in with anti inflammation and antioxidant effects ${ }^{15}$. Mangifer in is found to inhibit phagocytosis activity of macrophage and ROS formation $\frac{16,17}{}$. Elevation of ROS concentration causes oxidative stress impairing cells in the body including insulin receptor cells $s^{12}$.

\section{Conclusions}

In this study nanosilica inhalation and streptozotocin induction had shown to cause blood glucose elevation in Wistar rats and wearing N. exaltata inhibited blood glucose elevation in Wistar rats exposed to chronic nanosilica inhalation.

Research on human with high frequency of direct exposure to nanosilica such as farmers needs to be done to evaluate blood glucose level elevation. Future research on the effect of wearing $N$. exaltata mask against blood glucose level in Wistar rats that are chronically exposed to nanosilica needs to be done with higher frequency and longer duration of exposure.

\section{References}

1. Global Report on Diabetes. Date accessed: 2016 .https://apps.who.int/iris/bitstream/handle/10665/204871/9789241565257_eng.pdf;jsessionid=56 B80B83B577340F13B25090BB03E72E? sequence $=1$. 
2. Particulate Matter Air Pollution in an Urban Area: A Case Study. Date accessed: 12/2016. https://www. researchgate.net/publication/311739633_Particulate_ Matter_Air_Pollution_in_an_Urban_Area_a_Case_Study.

3. Association Between Fine Particulate Matter and Diabetes Prevalence in the U.S. Date accessed: 10/2010. https:// care.diabetesjournals.org/content/33/10/2196. https:// doi.org/10.2337/dc10-0698. PMid: 20628090, PMCid: PMC2945160.

4. Adams K, Greenbaum DS, Shaikh R, Erp AM Van, Russell AG, Adams K. Particulate matter components, sources, and health: Systematic approaches to testing effects, Journal of the Air and Waste Management Association. 2015; 65(5):544-58. https://doi.org/10.1080/10962247.2014.1001 884. PMid: 25947313.

5. Meigs JB. Association of oxidative stress, insulin resistance, and diabetes risk phenotypes: The Framingham Offspring Study, Diabetes Care. 2007; 30(10):1-12. https://doi. org/10.2337/dc07-0817. PMid: 17586736.

6. Pertaminingsih Lolita, Prihastanti Erma, Parman Sarjana, Subagio Agus, Ngadiwiyana Ngadiwiyana. Application of Inorganic Fertilizer With Nano Chisil and Nanosilica on Black Corn Plant Growth (Zea Mays L.), Journal of Physics: Conference Series. 2018; 1025. Date accessed: 05/2018. https:/www.researchgate.net/ publication/325445788_Application_of_Inorganic_ Fertilizer_With_NanoChisil_and_Nanosilica_on_Black_ Corn_Plant_Growth_Zea_Mays_L.

7. State of the Labor Force in Indonesia. Date accessed: 08/2018. https://translate.google.com/ translate?hl=en\&sl=id\&u=https://www.bps.go.id/publicati on/2018/11/30/6d8a8eb26ac657f7bd170fca/keadaan-angkatan-kerja-di-indonesia-agustus-2018.html\&prev=search.

8. Kurniawidjaja LM. The development of an effective workplace health promotion program to reduce cardiovascular disease risk in campus, Australian Journal of Basic and Applied Sciences. 2014; 8(6):397-403.

9. Interior Landscape Plants for Indoor Air Pollution Abatement. Date accessed: 1989. https://ntrs.nasa.gov/ search.jsp?R=19930073077.
10. Parasuraman S, Raveendran R, Kesavan R. Blood sample collection in small laboratory animals, Journal of Pharmacology and Pharmacotherapeutics. 2010; 1(2):8793.https://doi.org/10.4103/0976-500X.72350. PMid: 21350616, PMCid: PMC3043327.

11. Lawal AO. Air particulate matter induced oxidative stress and inflammation in cardiovascular disease and atherosclerosis: The role of Nrf2 and AhR-mediated pathways, Toxicology Letters. 2017; 270:88-95. https://doi. org/10.1016/j.toxlet.2017.01.017. PMid: 28189649.

12. Murugadoss S, Lison D, Godderis L, Brule S Van Den, Mast J, Brassinne F. Toxicology of silica nanoparticles: An update, Archives of Toxicology. 2017; 91(9):2967-3010. https://doi. org/10.1007/s00204-017-1993-y. PMid: 28573455, PMCid: PMC5562771.

13. Hurrle S, Hsu WH. The etiology of oxidative stress in insulin resistance, Biomedical Journal. 2017; 40(5):257-62 https://doi.org/10.1016/j.bj.2017.06.007. PMid: 29179880, PMCid: PMC6138814.

14. Pt F, Putra P, Pekalongan T. Relationship between work period and use of personal protective equipment with lung vital capacity in workers of spining unit i part of ring frame PT. Pisma Putra Pekalongan Textile, Unnes Journal of Public Health. 2013; 2(3):1-9.

15. Komala I, Betha OFAS, Muliati F, Mah MNI. Antioxidant and anti-inflammatory activity of the Indonesian ferns, Nephrolepis Falcata and Pyrrosia Lanceolata, International Journal of Pharmacy and Pharmaceutical Sciences. 2015; 7(12):12-15. https://innovareacademics.in/journals/index. php/ijpps/article/view/8751.

16. Naturally Occurring Xanthones: Chemistry and Biology. Date accessed: 2013. https://www.hindawi.com/journals/ jac/2013/621459/. https://doi.org/10.1155/2013/621459.

17. Singh S, Dhyani SK, Sharma S, Kumar SS. Phytochemical and Pharmacological investigation on Mangiferin, Herba Polonica. 2009; 55(1):126-39. 